\title{
The Effects of Cultivation Site on Forage Quality of Calliandra calothyrsus var. Patulul
}

\section{Journal Article}

\section{Author(s):}

Hess, H.D.; Tiemann, Tassilo T.; Noto, F.; Franzel, S.; Lascano, Carlos E.; Kreuzer, M.

Publication date:

2006-11

Permanent link:

https://doi.org/10.3929/ethz-b-000024199

Rights / license:

In Copyright - Non-Commercial Use Permitted

Originally published in:

Agroforestry Systems 68(3), https://doi.org/10.1007/s10457-006-9010-0 


\title{
The effects of cultivation site on forage quality of Calliandra calothyrsus var. Patulul
}

\author{
H. D. Hess $\cdot$ T. T. Tiemann $\cdot$ F. Noto $\cdot$ \\ S. Franzel · C. E. Lascano $\cdot$ M. Kreuzer
}

Received: 22 June 2005/ Accepted: 26 April 2006/Published online: 22 June 2006

(C) Springer Science+Business Media B.V. 2006

\begin{abstract}
An in vitro experiment was performed to compare the forage quality of foliage of Calliandra (Calliandra calothyrsus Meissner var. Patulul) cultivated on either low or medium-fertility soils in Colombia and Kenya, respectively. A grass-alone diet, with and without urea supplementation, and five legumesupplemented diets (1/3 of dietary dry matter) were tested with the rumen simulation technique (Rusitec) $(n=4)$. The legume supplements consisted of Cratylia (Cratylia argentea), Calliandra from Colombia or Kenya, or 1:1 mixtures of Cratylia with Calliandra Colombia or Kenya. The tannin content of Calliandra
\end{abstract}

H. D. Hess - T. T. Tiemann · F. Noto · M. Kreuzer Institute of Animal Science, Animal Nutrition, Swiss Federal Institute of Technology (ETH), ETH-Centre/ LFW, CH-8092 Zurich, Switzerland

C. E. Lascano · T. T. Tiemann

Tropical Grass and Legume Project, Centro

Internacional de Agricultura Tropical (CIAT), A.A.

6713 Cali, Colombia

S. Franzel

World Agroforestry Centre (ICRAF), 30677, Nairobi, Kenya

Present address: H. D. Hess ( $₫)$

Swiss Federal Research Station for Animal

Production and Dairy Products (ALP), Tioleyre 4,

CH-1725 Posieux, Switzerland

e-mail: dieter.hess@alp.admin.ch
Colombia was almost twice as high as that of Calliandra Kenya. Supplementation with urea or Cratylia alone, but not with Calliandra alone, increased ammonia concentration in the fermenter fluid. Unlike Calliandra Colombia, Calliandra Kenya in mixture with Cratylia increased ammonia concentration. The apparent degradation of organic matter increased with all types of supplementation, except with Calliandra Colombia alone. Although the foliage of Calliandra from the two cultivation sites had similar contents of organic matter, crude protein and neutral detergent fibre, they differed in nearly all fermentation properties. The material from Kenya showed a higher apparent nutrient degradability. These results indicate that $C$. calothyrsus var. Patulul cultivated at the Kenyan site had a clearly higher forage quality than foliage from the same variety cultivated in Colombia. However, both materials had a much lower forage quality than Cratylia. The Cratyliarelated effects on ruminal fermentation were mainly the results of an increased supply of fermentable nitrogenous compounds as was obvious from the comparison with the ureasupplemented grass.

Keywords Brachiaria humidicola Colombia · Cratylia argentea $\cdot \mathrm{Kenya} \cdot \mathrm{Ruminal}$ fermentation $\cdot$ Tannins 


\section{Introduction}

Insufficient quality of ruminant diets is prevalent in tropical agriculture and leads to low levels of livestock productivity. Protein deficiency is by far the most important cause of low performance of ruminants maintained on low-quality forages. Thus ensuring adequate ammonia levels in the rumen for microbial growth is the first priority in optimizing fermentative digestion of forages (Leng 1990). Utilization of trees and shrubs (named trees hereafter) is recognized to be an effective means of improving the supply and the quality of forage in tropical smallholder livestock systems. Green fodder from nitrogen-fixing leguminous trees contains much higher levels of rumen-degradable and undegradable protein than most grasses and crop residues (Hess et al. 2003, 2004a; Abreu et al. 2004). Calliandra (Calliandra calothyrsus Meissner), a tropical multipurpose tree legume, native to the humid and subhumid regions of Central America and Mexico, was introduced to the Central Highlands of Kenya in the 1980s and since then has been widely promoted and adopted as a supplement to ruminants on low-quality forages (Wambugu et al. 2001; Franzel et al. 2003). The initial promotion of Calliandra was based primarily on its promising agronomic attributes, which include fast growth and high biomass production of foliage and wood (reviewed by Tuwei et al. 2003). More recently, research has focused attention on the nutritional value of Calliandra. Although having a favourably high protein content (Lascano et al. 2003; Tuwei et al. 2003), reports of very high condensed tannin contents and low digestibility (Maasdorp et al. 1999; Hess et al. 2003; Lascano et al. 2003) have questioned its value as a supplement for ruminants fed low-quality forage. Nevertheless, on-farm trials with dairy animals in the Embu area of Kenya have suggested that Calliandra can substitute concentrate without adverse effects on milk yield (Paterson et al. 1999). Furthermore, Calliandra has been adopted by dairy cow and goat farmers in the Central Highlands of Kenya and is now being promoted in neighbouring Tanzania, Uganda and Rwanda (Tuwei et al. 2003). By contrast, this supplementation strategy has hardly been adopted by farmers in Colombia, where other legume trees such as Cratylia argentea are frequently used to supplement ruminant livestock during the dry season (Plazas and Lascano 2005). A previous in vitro study demonstrated that the supplementation of a low-quality grass with Calliandra grown in a site with acid, low-fertility soils in Colombia apparently does not improve the feeding value of the complete diet (Hess et al. 2003). However, there are certain indications that the feeding value of Calliandra could be affected by the cultivation site (Lascano et al. 2003). Thus the difference in adoption of Calliandra observed in Colombia and Kenya could be, apart from other reasons, due to contrasting forage qualities of Calliandra produced at sites with contrasting soil fertility and temperatures in the two countries.

The primary objective of the present study was to quantify possible differences in nutrient composition and in vitro ruminal fermentation characteristics of the same cultivar of Calliandra, but grown at sites in Colombia and Kenya, when incubated together with a tropical grass of low quality. This approach excluded both the cultivar effects and the between-experiment variations (e.g., due to differences in the composition of rumen microbes). Apart from a grass-only control, grass was supplemented either with urea or with Cratylia argentea, another tropical multipurpose legume with known forage potential (Hess et al. 2003, 2004a). Additionally, mixtures of Cratylia with Calliandra from the two sites were tested.

\section{Materials and methods}

\section{Plant material}

Four tropical forages were employed in the present experiment. The grass Brachiaria humidicola [formerly called Brachiaria dictyoneura, accession No. 6133 of the germplasm collection held at the Centro Internacional de Agricultura Tropical (CIAT)] grown in Colombia was used as the basal forage in all dietary treatments. Legume supplementation was performed with foliage of the multipurpose legume trees Cratylia (C. argentea (Desvaux) O. Kuntze; CIAT accession No. 18516/ 
18668) grown in Colombia and Calliandra (C. calothyrsus var. Patulul; CIAT accession No. 22316) grown in Colombia and Kenya.

In Colombia, the forages were cultivated at the Quilichao Research Station of CIAT located in the Southern Central Cordillera, Cauca district $\left(3^{\circ} 69^{\prime} \mathrm{N}, 76^{\circ} 31^{\prime} \mathrm{W}\right)$, at an altitude of $990 \mathrm{~m}$ a.s.l. The soil is classified as Oxisol with a $\mathrm{pH}$ of 4.5 , a high $\mathrm{Al}$ content and deficient in $\mathrm{P}$ and exchangeable cations. Rainfall is bimodal with an annual total of $1,727 \mathrm{~mm}(1,242-2,207 \mathrm{~mm})$, and the rains occur between March and June and between September and December. The annual mean temperature is $24^{\circ} \mathrm{C}$ with only small variations throughout the year $\left(23-25^{\circ} \mathrm{C}\right)$. In Kenya, Calliandra was cultivated at the Regional Research Centre, Embu, of the Kenya Agricultural Research Institute, located in the Central Highlands, on the southeastern slopes of Mt. Kenya $\left(0^{\circ} 27^{\prime} \mathrm{S}, 37^{\circ} 30^{\prime} \mathrm{E}\right)$, at an altitude of $1,480 \mathrm{~m}$ a.s.l. The soil is classified as humic Nitisol derived from basic volcanic rocks with deep, well weathered parent material, has a $\mathrm{pH}$ of 5.7, and is of moderate to high natural fertility. Rainfall is bimodal with an annual total of 1,200-1,400 mm and with the long rains occurring between mid-March and June $(650-750 \mathrm{~mm})$ and the short rains between mid-October and December (350-550 mm). In addition there is a cold misty period in July-August with light and unpredictable rainfall (50$250 \mathrm{~mm}$ ). Mean monthly temperature ranges from $17^{\circ} \mathrm{C}$ to $22^{\circ} \mathrm{C}$.

Legume foliage from Colombia and Kenya was harvested in December 2003 from mature plants after 6 month of regrowth since the last harvest and B. humidicola was collected from a pure sward after 4 months of regrowth. After harvest, all forages were oven-dried at $50^{\circ} \mathrm{C}$ and subsequently ground in a laboratory mill to pass a 5$\mathrm{mm}$ sieve. Fine forage particles were removed using a $0.25-\mathrm{mm}$ sieve in order to minimize particle losses out of the nylon bags during incubation in rumen fluid.

\section{Experimental design}

Seven dietary treatments were evaluated, a grassalone diet (negative control), a urea-supplemented grass diet (positive control) and five legume-supplemented diets. The legume supplements, always representing $1 / 3$ of dietary dry matter (DM), consisted of Cratylia (100\%), Calliandra from Colombia (100\%), Calliandra from Kenya (100\%), or mixtures (1:1) of Cratylia with Calliandra Colombia or Kenya. The amount of urea added to the grass in the positive control (9.5 $\mathrm{mg} \mathrm{g}^{-1}$ forage DM) was calculated using results of a previous study (Hess et al. 2003) to achieve similar ammonia concentrations as with the Cratylia-supplemented substrate. The dietary treatments were investigated during four experimental periods of 10 days each $(n=4)$.

\section{Experimental procedure}

The experiment was carried out in Switzerland with a rumen-simulation technique (Rusitec) as described before (Hess et al. 2003). An eightfermenter Rusitec-apparatus was applied by using always seven individual fermenters (i.e., one per treatment) and leaving one unused. Rumen fluid was collected from one non-lactating rumen-fistulated Brown Swiss cow for immediate use in the fermenters. The cow was housed according to Swiss guidelines for animal welfare and was fed hay (ad libitum) and a dairy cattle concentrate $\left(1 \mathrm{~kg} \mathrm{~d}^{-1}\right)$. Rumen fluid was strained through three layers of compress gauze $(1,000 \mu \mathrm{m}$ pore size, type 17, MedPro Novamed AG, Flawil, Switzerland). Fermenters were filled with $890 \mathrm{ml}$ of rumen fluid and $110 \mathrm{ml}$ of McDougall buffer. A precision pump guaranteed a continuous flow rate of artificial saliva (buffer) of $500 \mathrm{ml}$ per day to each fermenter, equivalent to a dilution rate of $0.50 \mathrm{~d}^{-1}$. The initial 4 days of each of the four experimental periods served for adaptation of the rumen microbes to the respective diets and the final 6 days for data collection.

Feed was put into nylon bags $(70 \mathrm{~mm} \times 130 \mathrm{~mm})$ with a pore size of $100 \mu \mathrm{m}$. At the start of the experimental periods, two nylon bags were placed into each fermenter. One of the bags contained $15 \mathrm{~g}$ DM of experimental feed (82 $\mathrm{mg}$ of feed DM cm${ }^{-2}$ nylon bag surface) and the other was filled with $60 \mathrm{~g}$ of fresh solid rumen content for easier establishment of favourable fermentation conditions. After $24 \mathrm{~h}$, the bags containing solid rumen content were 
replaced with bags containing the experimental feeds. Daily thereafter, those feed bags which had been incubated for $48 \mathrm{~h}$ were replaced. Directly following the replacement of the feed bags, fermenters were flushed with gaseous $\mathrm{N}_{2}$ to reestablish anaerobic conditions. After removal from the fermenters, feed bags were gently squeezed and rinsed for $20 \mathrm{~min}$ with cold tap water using a washing machine (Novamatic WA 163 standard, Fust, Zurich, Switzerland). Subsequently, fermentation residues were stored at $-20^{\circ} \mathrm{C}$ for later processing. Fermentation residues were lyophilized for $72 \mathrm{~h}$ prior to laboratory analyses, and both diet ingredients and fermentation residues were ground in a laboratory mill to pass a 1-mm sieve.

Samples of fermenter fluid were taken daily by means of a syringe $4 \mathrm{~h}$ before exchanging the nylon bags. Fermentation gases were collected in gas-proof bags (TECOBAG, 8 1, PETP/AL/PE12/12/75, Tesseraux Container GmbH, Bürstadt, Germany) and the total amount was quantified by the corresponding replacement of water.

\section{Analytical procedures}

Immediately after collection, $\mathrm{pH}$ and ammonia concentration of fermenter fluid were determined with a potentiometer (model 632, Metrohm, Herisau, Switzerland) equipped with the respective electrodes. Concentrations of volatile fatty acids (VFA) were determined according to Tangerman and Nagengast (1996) using gas chromatography (GC Star 3400 CX, Varian, Sugarland, TX, USA). The concentration of methane in fermentation gas was analysed using a second gas chromatograph (model 5890 Series II, Hewlett Packard, Avondale, PA, USA) equipped with a flame ionization detector. The column (Carboxen-1000; Fluka, Buchs, Switzerland) was $4.5 \mathrm{~m} \times 2.1 \mathrm{~mm}$ in size, and gas samples of $150 \mu \mathrm{l}$ were injected by a gastight syringe (1725 RN, Hamilton, Bonaduz, Switzerland). Argon was used as a carrier gas.

Counts of ciliate protozoa (daily) and total bacteria (on days 7 and 10) were determined in the fermenter fluid samples using Bürker counting chambers (Blau Brand, Wertheim, Germany) of 0.1 and $0.02 \mathrm{~mm}$ depth, respectively. Prior to counting, samples were fixed by addition of
$0.1 \mathrm{ml} \mathrm{ml}^{-1}$ (protozoa) and $0.99 \mathrm{ml} \mathrm{ml}^{-1}$ (bacteria) of Hayem solution $\left(\mathrm{mg} \mathrm{ml}^{-1}, \mathrm{HgCl}_{2}, 2.5\right.$; $\left.\mathrm{Na}_{2} \mathrm{SO}_{4}, 25.0 ; \mathrm{NaCl}, 5.0\right)$.

All air-dry feeds and fermentation residues were subject to analysis of $\mathrm{DM}\left(105^{\circ} \mathrm{C}\right.$ for $\left.12 \mathrm{~h}\right)$, total ash $\left(500^{\circ} \mathrm{C}\right.$ for $\left.3 \mathrm{~h}\right)$, neutral detergent fibre (NDF), and acid detergent fibre (ADF) (Van Soest et al. 1991). A heat stable $\alpha$-amylase (Termamyl 120L, type S, Novo Nodirsk A/S, Bagsværd, Denmark) and sodium sulphite were used for NDF determination, and values of NDF and ADF were corrected for ash content. Additionally, diet ingredients were analysed for acid detergent lignin (Van Soest et al. 1991). A C/N analyser (type FP-2000, Leco Instrumente $\mathrm{GmbH}$, Kirchheim, Germany) was used to determine $\mathrm{N}$, with crude protein $(\mathrm{CP})$ being calculated as $\mathrm{N} \times 6.25$.

Legume foliages were further analysed for their contents of extractable and bound condensed tannins according to the butanol $/ \mathrm{HCl}$ procedure as suggested by Terrill et al. (1992). The extraction was completed with an aqueous methanol $\left(700 \mathrm{ml} \mathrm{l}^{-1}\right)$, formic acid $\left(5 \mathrm{ml} \mathrm{l}^{-1}\right)$ and ascorbic acid $\left(0.5 \mathrm{~g} \mathrm{l}^{-1}\right)$ solution. Purified tannins, previously obtained from each material by the procedure of Hagerman and Butler (1980), were used as standards.

Calculations and statistical analyses

The apparent in vitro extent of organic matter (OM), CP, NDF and ADF degradation was calculated from the respective amounts present in the nylon bags before and after $48 \mathrm{~h}$ of incubation. Variables of in vitro $\mathrm{N}$ turnover were calculated from the apparent $\mathrm{N}$ disappearance from the nylon bags and the daily amounts of ammonia produced. Four $\mathrm{N}$ fractions were computed: (i) $\mathrm{N}$ present in apparently degraded nitrogenous compounds (further on called 'apparently degraded N'), (ii) $\mathrm{N}$ recovered as ammonia $\mathrm{N}$, (iii) $\mathrm{N}$ apparently degraded but not recovered as ammonia $\mathrm{N}$ [i.e., (iii) = (i)-(ii)], and (iv) dietary $\mathrm{N}$ compounds apparently remaining undegraded. Fraction (iii) was assumed to be largely incorporated into microbes, and microbial efficiency was consequently estimated as mg of fraction (iii) per $\mathrm{g}$ of OM apparently degraded. 
Data were subjected to analysis of variance using the GLM procedure of SAS (SAS 1996; version 8.2 for Windows, SAS Institute, Cary, NC, USA). Diet and experimental period were considered as sources of variance. Prior to the analysis, data were averaged across days 5-10 for each fermenter and period $(n=4)$. Multiple comparisons among means were performed with Tukey's method. Furthermore, orthogonal contrasts were used to compare substrates containing Calliandra from Colombia with those containing Calliandra from Kenya $(n=8)$. The tables give treatment means, standard error of the means (SEM) and the result of the orthogonal contrast analysis.

\section{Results}

Composition of the feeds

The grass (Brachiaria humidicola) was very low in $\mathrm{CP}$ and high in NDF and ADF (Table 1) in line with its known low feeding value. Independent of species and growing site, the legume foliages were higher in CP and lower in NDF and ADF than the grass, but also had higher lignin contents. The $\mathrm{CP}$ content of the two legume species was fairly uniform but NDF, ADF and lignin contents were higher in Cratylia than in Calliandra. Calliandra Colombia and Calliandra Kenya had similar contents of $\mathrm{OM}, \mathrm{CP}$ and fibre, but the concentration of extractable condensed tannins was almost twice as high in Calliandra Colombia than in Calliandra Kenya. Due to the differences in chemical composition of the individual feed ingredients, the complete diets also varied in their composition (Table 2). Legume supplementation increased CP content quite uniformly by about threefold and, particularly with Calliandra, reduced fibre contents by up to $165 \mathrm{mg} \mathrm{g}^{-1} \mathrm{DM}$. The $\mathrm{N}$ content of the urea-supplemented grass diet was intermediate.

Fermenter fluid characteristics

The $\mathrm{pH}$ of the fermenter fluid decreased $(P<0.05)$ with urea or legume supplementation

Table 1 Analysed chemical composition ( $\mathrm{mg} \mathrm{g}^{-1}$ dry matter) of the experimental forages

\begin{tabular}{lllrl}
\hline Country of origin & Brachiaria humidicola & Cratylia argentea & \multicolumn{2}{c}{ Calliandra calothyrsus } \\
\cline { 3 - 5 } & Colombia & Colombia & Colombia & Kenya \\
\hline Organic matter & 889 & 925 & 937 & 944 \\
Crude protein & 35 & 228 & 205 & 220 \\
Neutral detergent fibre & 720 & 479 & 260 & 285 \\
Acid detergent fibre & 392 & 343 & 63 & 252 \\
Acid detergent lignin & 41 & 147 & 382 & 208 \\
Extractable condensed tannins $^{\text {a }}$ & na & nd & 23 & 26 \\
Bound condensed tannins $^{\text {a }}$ & na & & & \\
\hline
\end{tabular}

ana, not analysed; nd, not detected

Table 2 Analysed chemical composition ( $\mathrm{mg} \mathrm{g}^{-1}$ dry matter) of the complete diets $(n=4)$

\begin{tabular}{|c|c|c|c|c|c|c|c|}
\hline \multirow{3}{*}{$\begin{array}{l}\text { Brachiaria humidicola proportion } \\
\text { Legume supplement } \\
\text { Origin of Calliandra }\end{array}$} & \multirow[t]{3}{*}{$3 / 3$} & \multirow[t]{3}{*}{$3 / 3^{a}$} & \multicolumn{5}{|l|}{$2 / 3$} \\
\hline & & & \multirow[t]{2}{*}{ Cratylia argentea } & \multicolumn{2}{|c|}{$\begin{array}{l}\text { Cratylia argentea \& } \\
\text { Calliandra calothyr- } \\
\text { sus }\end{array}$} & \multicolumn{2}{|c|}{$\begin{array}{l}\text { Calliandra calothyr- } \\
\text { sus }\end{array}$} \\
\hline & & & & Colombia & Kenya & Colombia & Kenya \\
\hline Organic matter & 889 & 889 & 898 & 902 & 899 & 902 & 905 \\
\hline Crude protein & 35 & 60 & 97 & 94 & 97 & 91 & 96 \\
\hline Neutral detergent fibre & 720 & 704 & 638 & 601 & 606 & 555 & 576 \\
\hline Acid detergent fibre & 392 & 388 & 377 & 355 & 368 & 330 & 347 \\
\hline
\end{tabular}

${ }^{\mathrm{a}}$ supplemented with $9.5 \mathrm{mg}$ of urea per gram of forage dry matter 
except when Calliandra Colombia was used as a supplement alone (Table 3). The mean redox potential over all treatments was $-304 \mathrm{mV}$, and effects of supplementation were minor indicating similar anaerobic conditions.

Ammonia concentration was increased $(P<0.05)$ by supplementation with urea or Cratylia alone but was not affected $(P>0.05)$ by supplementation with Calliandra alone. Supplementation with the legume mixtures lead to an increase in ammonia concentration, but this increase was only significant $(P<0.05)$ when Calliandra Kenya was employed in the mixture. Overall, supplementation with Calliandra Kenya resulted in higher $(P<0.01)$ ammonia concentrations than supplementation with Calliandra Colombia.

Total VFA concentration increased $(P<0.05)$ with any type of supplementation but, compared to the grass-alone treatment, no changes occurred $(P>0.05)$ in the molar proportion of the major VFA or in the acetate-to-propionate ratio. In contrast, the proportion of the minor VFA isovalerate was increased by Cratylia and decreased by Calliandra supplementation $(P<0.05)$. Counts of ciliate protozoa and bacteria were not affected $(P>0.05)$ by urea or legume supplementation.

Apparent nutrient degradation and methane emission

The apparent degradation of OM increased $(P<0.05)$ with any type of supplementation, except when the supplement consisted of pure Calliandra Colombia (Table 4). Supplementation with either urea, Cratylia or the legume mixtures increased $(P<0.05)$ the apparent NDF degradation, while supplementation with Calliandra alone had no effect $(P>0.05)$. The apparent ADF degradation increased $(P<0.05)$ with supplementation of urea, Cratylia alone and the mixture of Calliandra Kenya with Cratylia. The extent of apparent OM degradation was higher $(P<0.05)$ and fibre degradation tended to be higher $(P<0.1)$ in diets containing Calliandra from Kenya compared to that from Colombia.

Methane release (daily and relative to $\mathrm{OM}$ apparently degraded) increased $(P<0.05)$ with all types of supplementation, except when the sup- plement only consisted of Calliandra Colombia. Diets containing Calliandra Kenya resulted in a $10-20 \%$ higher daily methane release $(P<0.01)$ than those containing Calliandra Colombia.

\section{In vitro nitrogen turnover}

The increase in nitrogen supply to the fermenters with all types of supplementation resulted in significant effects of supplementation on most variables related to $\mathrm{N}$ turnover, not only in absolute terms but also relative to $\mathrm{N}$ supply (Table 5). The extent of apparent degradation of nitrogenous compounds ( $\mathrm{mg} \mathrm{g}^{-1}$ of $\mathrm{N}$ supply) was increased $(P<0.05)$ by supplementation with urea or Cratylia but remained unaffected $(P>0.05)$ by supplementation with the legume mixtures, and was decreased $(P<0.05)$ by supplementation with Calliandra alone. The proportion of $\mathrm{N}$ recovered in ammonia increased $(P<0.05)$ with supplementation of urea or Cratylia, while supplementation with Calliandra alone or in mixture with Cratylia had no effect on this $\mathrm{N}$ fraction. The proportion of $\mathrm{N}$ presumed to be incorporated into microbial protein was not significantly affected $(P>0.05)$ by supplementation with urea, Cratylia, the legume mixtures or Calliandra Kenya, but decreased $(P<0.05)$ when Calliandra Colombia was supplemented alone. The estimated microbial efficiency was not affected $(P>0.05)$ by urea supplementation and was increased $(P<0.05)$ with all legume supplementation treatments. Compared to Calliandra Colombia, supplementation with Calliandra Kenya resulted in higher proportions of $\mathrm{N}$ degraded, of $\mathrm{N}$ recovered in ammonia and of $\mathrm{N}$ presumed to be incorporated in microbial protein, leading to a higher estimated microbial efficiency $(P<0.05)$.

\section{Discussion and conclusions}

Small holder ruminant feeding systems in the tropics heavily rely on pastures and crop residues. These forages usually have high fibre contents and are deficient in $\mathrm{N}$, which restricts feed intake and the efficiency of feed utilization. Under such conditions, products of the fermentative digestion (e.g., volatile fatty acids and microbial protein) 


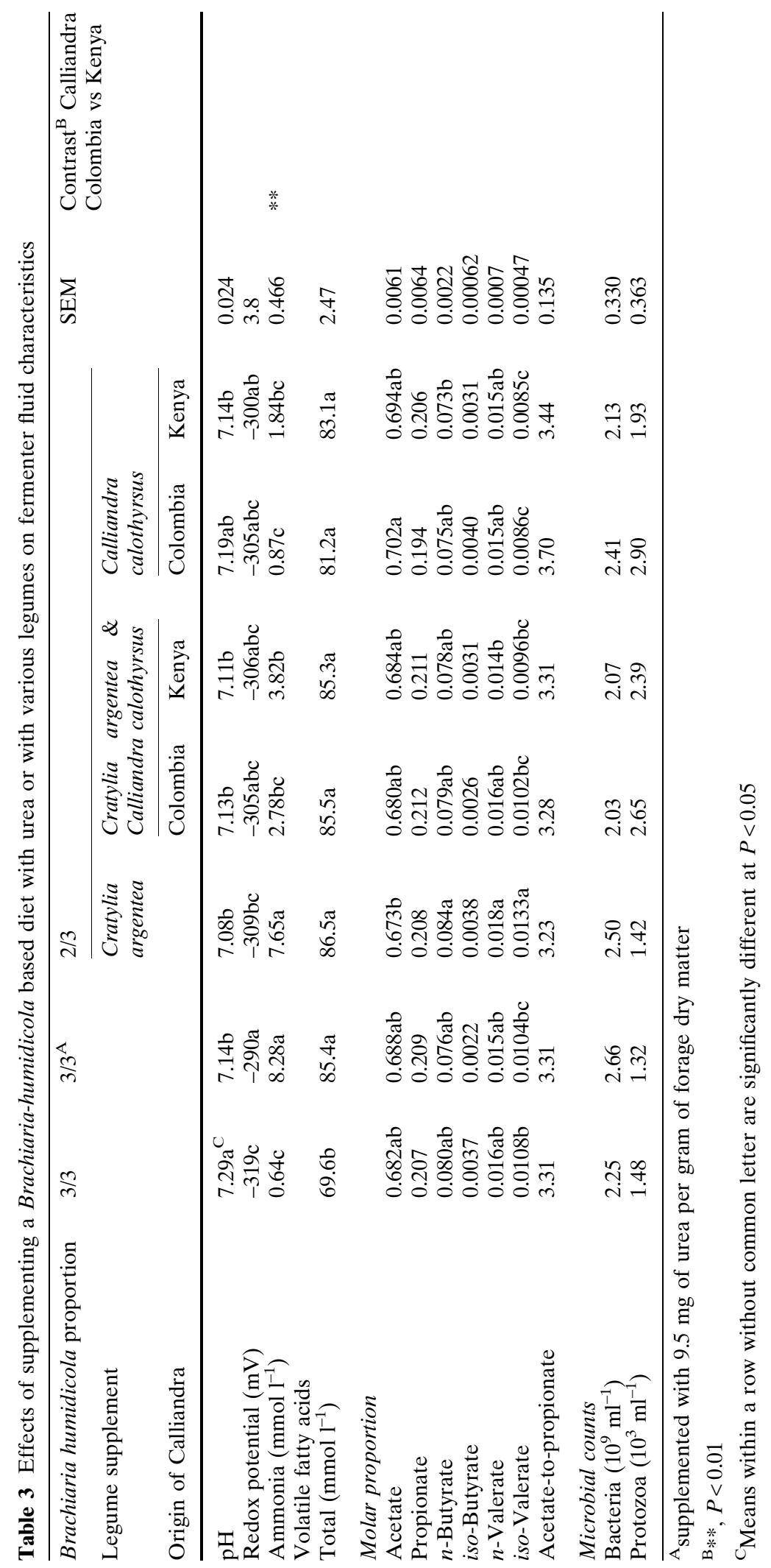




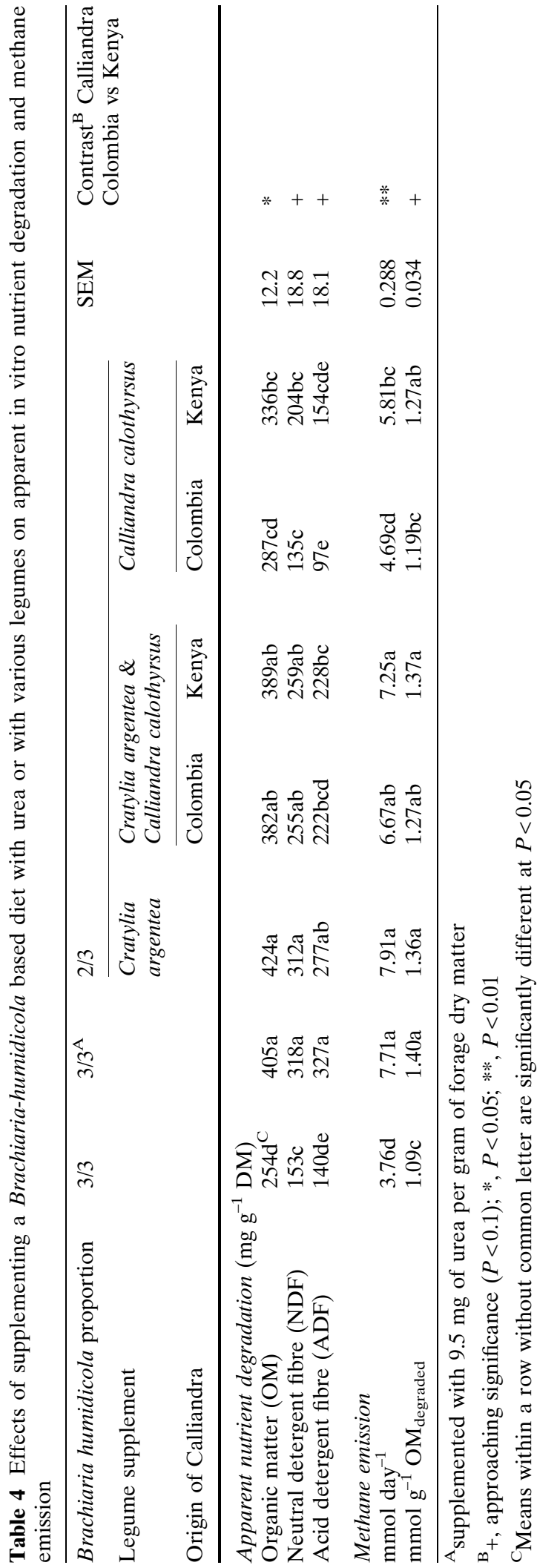

are the major source of nutrients for ruminant livestock. Enhancing ruminal digestion and microbial growth is therefore of highest priority for supplementation strategies based on multipurpose legume trees to improve the utilization of low-quality forages by ruminants (Leng 1990).

\section{Effects of supplementation}

The sample of Brachiaria humidicola used in this experiment presented a very low forage quality ( $<40 \mathrm{mg}$ of $\mathrm{CP}$ and $>700 \mathrm{mg}$ of NDF per $\mathrm{g}$ of DM) typical for many tropical pasture grasses. The values agreed well with those reported previously for $B$. humidicola cultivated under similar environmental conditions (Hess et al. 2003, 2004a; Abreu et al. 2004). With such low-quality forages, rumen microbial fermentation activity is often limited by the shortage of one or more essential nutrients, typically $\mathrm{N}$, which results in low concentrations of ruminal fluid ammonia and, consequently, low $\mathrm{OM}$ and fibre degradation (Leng 1990).

Supplementation with urea or Cratylia increased the supply of fermentable $\mathrm{N}$ compounds to a similar extent as intended, as was apparent from similar and high ammonia concentrations in the fermentation fluid. Although microbial counts were not affected by these supplements, microbial activity was enhanced and OM and fibre degradation as well as the VFA concentration increased to a similar extent with both urea and Cratylia supplementation. This suggests that the low apparent fibre degradation in the grass-alone substrate resulted mainly from a lack of fermentable $\mathrm{N}$, and this lack of $\mathrm{N}$ could be compensated equally well by supplementation with a legume free of tannins as with urea. The increase in $\mathrm{OM}$ and fibre degradation with urea or Cratylia was accompanied by an increase in methane emission, both per day and per unit of $\mathrm{OM}$ apparently fermented. This is consistent with results from a previous in vitro study (Hess et al. 2003).

Although providing similar amounts of total dietary N, all supplements containing Calliandra were less effective in modifying fermentation than urea or Cratylia alone. Supplementation with Calliandra alone increased the amount of 


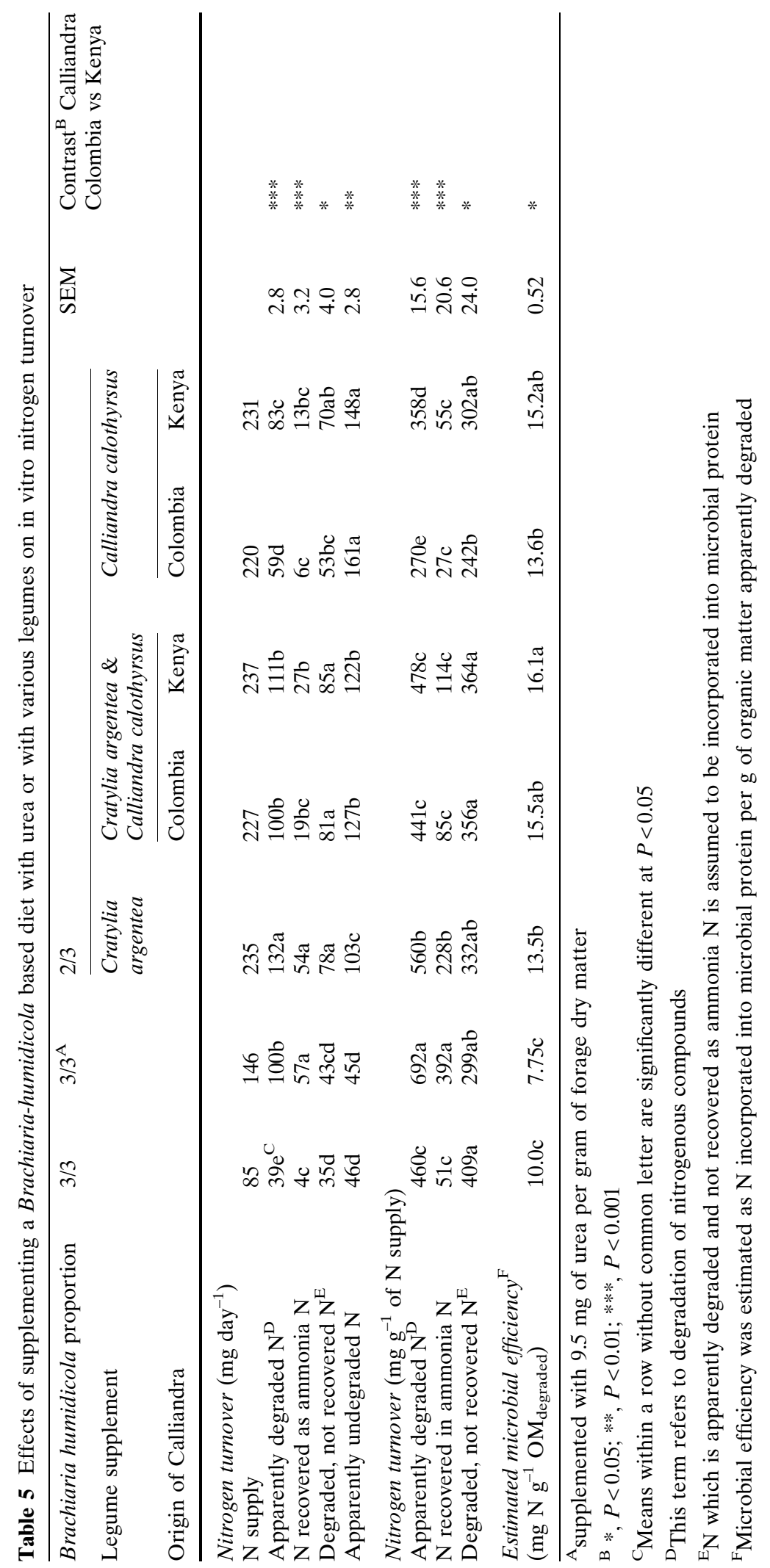


apparently degraded $\mathrm{N}$ but, relative to $\mathrm{N}$ supply, $\mathrm{N}$ degradation was suppressed compared to all other substrates. This was presumably due to the high tannin concentration in Calliandra. There is general agreement that tannins suppress ruminal degradation of nitrogenous compounds, mainly because of the formation of tannin-protein complexes which are hardly degraded by ruminal microbes (Broderick and Albrecht 1997).

In the present study, the suppressed proportion of $\mathrm{N}$ apparently degraded was associated with lower molar proportions of iso-valerate (a product of the degradation of certain amino acids; France and Siddons 1993) and lower ammonia concentrations in the fermenter fluid. The latter is consistent with observations made in vitro (Hess et al. 2003, 2004b) and in vivo (Carulla et al. 2001; Carulla et al. 2005) when supplementing with tanniniferous feeds. The low ammonia concentrations probably contributed indirectly to the inhibition of NDF degradation in the substrates containing Calliandra and in the unsupplemented control. However, in the treatments with Calliandra, a direct inhibition of fibrolytic microbes either through tannin interactions with the microbial cell wall and its secreted enzymes or a reduced substrate availability caused by the formation of complexes of tannins with structural carbohydrates cannot be excluded (McSweeney et al. 2001).

Even though condensed tannins may selectively suppress certain microbial populations in the rumen (McSweeney et al. 2001), Makkar et al. (1995) have shown in vitro that tannins can increase the overall efficiency of microbial protein synthesis. In the present study, the highest estimated efficiency was observed with the legume mixture containing Calliandra Kenya (intermediate tannin content) and the lowest values with pure Cratylia or Calliandra Colombia (lowest and highest tannin content, respectively). This suggests that there might be an optimum concentration of condensed tannins from Calliandra related to the efficiency of fermentation.

In agreement with previous observations (Hess et al. 2003), methane emission decreased when Cratylia was replaced with Calliandra. This suggests that tannin-rich legumes such as Calliandra could contribute to reduce methane emission from ruminal fermentation. However, this decrease was less pronounced with Calliandra Kenya than with Calliandra Colombia and was accompanied by a reduction in the feeding value of the mixed diet as well.

Effects of the cultivation site

For foliage of $C$. calothyrsus var. Patulul grown at Embu in Kenya, an average CP content of $220 \mathrm{mg} \mathrm{g}^{-1} \mathrm{DM}$ was reported by Tuwei et al. (2003), which is identical to the value found in the present study. The CP content of the same cultivar grown at Quilichao in Colombia was slightly lower (205 $\left.\mathrm{mg} \mathrm{g}^{-1} \mathrm{DM}\right)$ but exceeded the range of $135-160 \mathrm{mg} \mathrm{g}^{-1} \mathrm{DM}$ reported previously for this provenance grown at the same site in Colombia (Hess et al. 2003; Lascano et al. 2003). The reasons for these differences among studies are not clear but could be related to differences in the age of the plant material or in the proportion of leaves and stems in the samples analysed.

The reports in the literature on total condensed tannin content of $C$. calothyrsus var. Patulul grown at Quilichao range from 270 (Hess et al. 2003) to $394 \mathrm{mg} \mathrm{g}^{-1} \mathrm{DM}$ (Lascano et al. 2003). At another site in Colombia with more fertile and less acidic soils, Lascano et al. (2003) found a total condensed tannin content of $372 \mathrm{mg} \mathrm{g}^{-1}$ DM. The value observed in the present study (405 $\mathrm{mg} \mathrm{g}^{-1} \mathrm{DM}$ ) slightly exceeded this range. In contrast, the content of total condensed tannins in C. calothyrsus var. Patulul grown at Embu (234 $\mathrm{mg} \mathrm{g}^{-1} \mathrm{DM}$ ) was far below the mean value of $359 \mathrm{mg} \mathrm{g}^{-1}$ DM reported by Tuwei et al. (2003). These data indicate that forage composition for a single variety, particularly the content of condensed tannins, may vary between sites, and that variation at a particular site may also be substantial. Variations at a given site could be related to seasonal changes (e.g., temperature, rainfall) or to differences in plant maturity. In the study of Tuwei et al. (2003) performed at Embu in Kenya, the content of condensed tannins of $C$. calothyrsus var. Patulul varied seasonally from around 200 to over $400 \mathrm{mg} \mathrm{g}^{-1} \mathrm{DM}$. But also differences in sample collection and processing could contribute to the variability among the different studies (Stewart et al. 2000). Differences between sites 
additionally could be due to variations in soil nutrient status, macro climate and altitude.

In the present experiment, the nutrient composition of Calliandra from Colombia and Kenya was relatively similar, but the tannin content was almost twice as high in Calliandra grown in Colombia as in that cultivated in Kenya. This resulted in significant differences in nearly all fermentation properties, and is indicative of a higher feeding value of Calliandra originating from the Kenyan site. This was particularly pronounced in the apparent degradation of nitrogenous compounds, suggesting that the contrasting content of tannins was really the major factor causing variation in fermentation parameters between the Calliandra forage harvested in Kenya and in Colombia.

It can be concluded from the present results that the forage quality of foliage from C. calothyrsus var. Patulul may vary considerably across cultivation sites. Among other factors (e.g., type of farming systems, land holding size, labour availability etc.) these contrasting forage qualities of Calliandra produced in Colombia and Kenya might have contributed to the difference in adoption rates of Calliandra as a forage supplement for livestock observed in these countries. In Colombia other multipurpose legume trees with better forage quality such as Cratylia have been adopted despite less favourable agronomic performance. Further research is required to identify the environmental factors (e.g., soil type and fertility, climate) responsible for these differences in forage quality and content of condensed tannins across cultivation sites. The characterization of these factors would contribute to better predict the adoption potential of Calliandra and could eventually help to identify potential areas for future extension work. Further research is also needed to explain the causes of variation in condensed tannin content at a given site. The large range of condensed tannin contents in C. calothyrsus var. Patulul reported in the literature and observed in the present study stresses the importance of repeated measurements of this particular plant compound. Furthermore, the results clearly demonstrated that Calliandra from both cultivation sites has a much lower nutritional value than Cratylia. Finally, the implementation of Calliandra-based feeding systems could contribute to mitigate methane emission from ruminant husbandry.

Certain limitations in generalization of the results are given by the fact that the rumen fluid used in this study was from one single donor animal which was not adapted to the experimental diets, but this procedure also helped to standardise conditions, and the observed changes in ruminal fermentation reflect those which can be expected in unadapted tropical ruminants. Furthermore it has to be kept in mind, that in this study only the chemical composition and the ruminal fermentation characteristics were considered. It is likely that the decrease in the apparent degradation of $\mathrm{CP}$ observed when supplementing with Calliandra, would result in a greater flow of dietary $\mathrm{CP}$ to the lower digestive tract of ruminants fed such mixtures. If a certain amount of this undegraded CP would be available for digestion and absorption in the lower tract, this could result in an increased animal performance (Min et al. 2003). This, however, has to be confirmed in feeding experiments where effects on $\mathrm{N}$ digestion and utilization in the lower digestive tract can be assessed.

Acknowledgements This study was supported by the Swiss Agency for Development and Cooperation (SDC) and the Swiss Centre for International Agriculture (ZIL). The authors are grateful to P. Avila, B. Schneider, C.R. Soliva and C. Wambugu for their assistance in this study.

\section{References}

Abreu A, Carulla JE, Lascano CE, Díaz TE, Kreuzer M, Hess HD (2004) Effects of Sapindus saponaria fruits on ruminal fermentation and duodenal nitrogen flow of sheep fed a tropical grass diet with and without legume. J Animal Sci 82:1392-1400

Broderick GA, Albrecht KA (1997) Ruminal in vitro degradation of protein in tannin-free and tannincontaining forage legume species. Crop Sci 37:18841891

Carulla JE, Kreuzer M, Machmüller A, Hess HD (2005) Supplementation of Acacia mearnsii tannins decrease methanogenesis and urinary nitrogen in forage-fed sheep. Aust J Agric Res 56:961-970

Carulla J, Lascano C, Klopfenstein T (2001) Reduction of tannin level in a tropical legume (Desmodium ovalifolium) with polyethylene glycol (PEG): effects on intake and $\mathrm{N}$ balance, digestion and absorption by sheep. Archivos Latinoamericanos de Producción Animal 9:17-24 
France J, Siddons RC (1993) Volatile fatty acid production. In: Forbes JM, France J (eds) Quantitative aspects of ruminant digestion and metabolism. CAB International, Oxon UK, pp 107-121

Franzel S, Wambugu C, Tuwei P, Karanja G (2003) The adoption and scaling up of the use of fodder shrubs in central Kenya. Trop Grasslands 37:239-250

Hagerman AE, Butler L (1980) Condensed tannin purification and characterization of tannin-associated proteins. J Agric Food Chem 28:947-952

Hess HD, Beuret RA, Lötscher M, Hindrichsen IK, Machmüller A, Carulla JE, Lascano CE, Kreuzer M (2004a) Ruminal fermentation, methanogenesis and nitrogen utilization of sheep receiving tropical grass hay-concentrate diets offered with Sapindus saponaria fruits and Cratylia argentea foliage. Animal Sci 79:177-189

Hess HD, Monsalve LM, Lascano CE, Carulla JE, Díaz TE, Kreuzer M (2003) Supplementation of a tropical grass diet with forage legumes and Sapindus saponaria fruits: effects on in vitro ruminal nitrogen turnover and methanogenesis. Aust J Agric Res 54:703-713

Hess HD, Valencia FL, Monsalve LM, Lascano CE, Kreuzer M (2004b) Effects of tannins in Calliandra calothyrsus and supplemental molasses on ruminal fermentation in vitro. J Animal Feed Sci 13(Suppl. 1):95-98

Lascano C, Avila P, Stewart J (2003) Intake, digestibility and nitrogen utilization by sheep fed with provenances of Calliandra calothyrsus Meissner with different tannin structure. Archivos Latinoamericanos de Producción Animal 11:21-28

Leng RA (1990) Factors affecting the utilization of 'poorquality' forages by ruminants particularly under tropical conditions. Nutr Res Rev 3:277-303

Makkar HPS, Blümmel M, Becker K (1995) In vitro effects of and interactions between tannins and saponins and fate of tannins in the rumen. J Sci Food Agric 69:481-493

Maasdorp BV, Muchenje V, Titterton M (1999) Palatability and effect on dairy cow milk yield of dried fodder from the forage trees Acacia boliviana, Calliandra calothyrsus and Leucaena leucocephala. Animal Feed Sci Technol 77:49-59

McSweeney CS, Palmer B, Bunch R, Krause DO (2001) Effect of the tropical forage calliandra on microbial protein synthesis and ecology in the rumen. J Appl Microbiol 90:78-88

Min BR, Barry TN, Attwood GT, McNabb WC (2003) The effect of condensed tannins on the nutrition and health of ruminants fed fresh temperate forages: a review. Animal Feed Sci Technol 106:3-19

Paterson RT, Kiruiro E, Arimi HK (1999) Calliandra calothyrsus as a supplement for milk production in the Kenya Highlands. Trop Animal Health Product 31:115-126

Plazas CH, Lascano CE (2005) Utilidad de Cratylia argentea en ganaderias de doble proposito del piedemonte de los llanos orientales de Colombia. Pasturas Trop 27:65-72

Stewart JL, Mould F, Mueller-Harvey I (2000) The effect of drying treatment on the fodder quality and tannin content of two provenances of Calliandra calothyrsus Meissner. J Sci Food Agric 80:1461-1468

Tangerman A, Nagengast FM (1996) A gas chromatographic analysis of fecal short-chain fatty acids, using the direct injection method. Anal Biochem 236:1-8

Terrill TH, Rowan AM, Douglas GB, Barry TN (1992) Determination of extractable and bound condensed tannin concentrations in forage plants, protein concentrate meals and cereal grains. J Sci Food Agric 58:321-329

Tuwei PK, Kang'ara JNN, Mueller-Harvey I, Poole J, Ngugi FK, Stewart JL (2003) Factors affecting biomass production and nutritive value of Calliandra calothyrsus leaf as fodder for ruminants. J Agric Sci (Camb.) 141:113-127

Van Soest PJ, Robertson JB, Lewis BA (1991) Methods for dietary fiber, neutral detergent fiber, and nonstarch polysaccharides in relation to animal nutrition. J Dairy Sci 74:3583-3597

Wambugu C, Franzel S, Tuwei P, Karanja G (2001) Scaling up the use of fodder shrubs in central Kenya. Dev Pract 11:487-494 